\title{
Art, Culture, and Chinese-American Students: An On Going Case Study at a Chinese Community-based School
}

\section{Mei-Fen Chen}

The United States of America is populated by peoples of different cultural backgrounds and ethnic origins. McFee (1991) described an ideal art education as one that "should enable individuals to be multicultural in their responses and understand many arts within their subcultural systems, and thus have a more definitive basis for comparing them" (p. 72). The implication is that arts of all cultures and of all social classes can be analyzed, critiqued, and accepted as art in terms of different groups' value systems. However, McFee (1991) indicated that America's schools have become monocultural environments. Large percentages of students are living with cultural realities other than those found in schools. Children are often the victims of assimilation school policies.

Research studies relating to multicultural education have increased in recent years. According to Sleeter and Grant (1987), most multicultural education books and articles focus heavily on the individual classroom teacher as the agent of school change. Little attention is directed specifically to those community groups who may have a stake in school reform. In fact, many ethnic groups have established private community-based ethnic schools that are outside the public educational system of American society as a whole. For example, in many cities in the United States, Chinese-American groups operate community-based Chinese schools for Chinese-American students to learn about Chinese art and their cultural heritage. Therefore, community-based ethnic schools are an important source for art educators to understand more about Chinese-American students who are in their art classes.

The purpose of this case study is to provide an understanding of Chinese-American students' experiences in learning Chinese culture and art, and to facilitate a broader understanding of sociocultural contexts that affect those Chinese-American students' lives and learning outside regular art classrooms. This research focuses on what happens when Chinese-American students learn about Chinese art, what forms their art making takes and why, and how they respond to the Chinese art learning process. Furthermore, this study explores how all of these factors influence Chinese-American students both at a community-based school and at a regular public school, and how these factors may bridge Chinese-American students' transactions between Western and Eastern worlds. 


\section{Multicultural Education}

In the late 1960 s and early 1970 s, there were several related movements in the United States that endeavored to make education equitable for various groups. Multicultural education is one of these reform movements aimed at changing the contents and processes of education within schools (Sleeter and Grant, 1987). In recent years, numerous researchers have proposed that American education needs to be focused with more attention to multicultural education (e.g., Banks, 1981; Bennett, 1986; Sleeter and Grant, 1988; Wurzel, 1988; Hernandez, 1989). The concept of assimilation into the 'melting pot' is disappearing in the Untied States. The role of schools is quickly changing from passing on traditional knowledge to being concerned with group and ethnic interests as parts of a comprehensive knowledge base (Zimmerman, 1991).

The phrase 'multicultural education' is conceived by researchers in a variety of ways. Sleeter and Grant (1988) summarized five approaches to multicultural education that include: (1) teaching culturally different students and attempting to assimilate students of color into mainstream; (2) helping students from various cultural backgrounds build strong self concepts; (3) focusing on contributions of a particular cultural group by students from the same group or from different backgrounds; (4) integrating contributions of many different cultural groups and cultural values; and (5) promoting social action positions in which problems involving racism, sexism, and inequity are stressed as much as teaching of cultural values.

Goodenough (1971) defined culture as knowledge, as the shared and learned patterns of information a group uses in order to generate meaning among its members. Culture is not static, as Wurzel (1988) argued, and it is intrinsically dynamic and developmental. Wurzel proposed a model of multicultural education that is not only an instructional product but a continuous process involving: (1) reflection, learning and the development of cultural self-awareness, (2) acceptance of conflict for its educational potential, (3) willingness to learn about one's own cultural reality from interaction with others, (4) improvement of communication with people from other cultures, and (5) recognition of the universality of multiculturalism. Taking each point in Wurzel's definition of multicultural education and applying it to art education, Wurzel's approach will be used to build a theoretical perspective to analyze the art experiences of Chinese-American students at a community-based school. In particular, the impacts faced by Chinese-American students during the Chinese art learning processes of self-reflection, self-identity, culture difference, culture conflict, and acceptance of other cultures as Wurzel proposed will be the main issues of this research.

\section{Hyphenated Americans}

Grigsby (1977) insisted that all people are ethnic, although he noted that as used in popular language, the term 'ethnic' is used only as a means of 
identifying members of minority groups in the united States, such as NativeAmericans, Afro-Americans, Mexican-Americans, Asian-Americans, and firstor second- generation Europeans who also are hyphenated-Americans. Hill (1990) also stated that Wagley and Marin defined minorities as social groups whose members experience various disabilities at the hands of a dominant group. The categories 'racial', 'ethnic', and 'cultural' identify such groups as minorities.

In regard to the changing dynamics of ethnic groups in the United States, Sleeter and Grant (1988) proposed using Newman's model (1973) for an explanation because it is relevant to a multicultural education approach. The model $\mathrm{A}+\mathrm{B}+\mathrm{C}=\mathrm{A}_{1}+\mathrm{B}_{1}+\mathrm{C}_{1}$ demonstrates a concept of modified cultural differences, in which $A, B$, and $C$ represent different social groups that, over time, modify their original cultural identities into $A_{1}, B_{1}$, and $C_{1}$. As Newman pointed out, "an Italian in Italy is different from an Italian-American" (p. 134). Thus, it can be inferred that a Chinese person in China is different from a Chinese-American. The concept of cultural difference holds that various ethnic, religious, and racial groups will assimilate into a dominant group to some extent, but that this will vary with the group, and many groups will continue to retain their unique cultural characteristics after several generations in the United States.

\section{Cultural Difference}

Yao (1983) indicated that the assimilation process of each individual ethnic group varies according to the degree of differences between intrinsic cultural traits of the ethnic group and those of the core society. Even though first-generation immigrant parents are inclined to maintain their ethnicity, they lack power to combat external forces that accelerate the assimilation process of their children which may manifest itself in self-denial, including denial of their ethnic identity. This is particularly true among second- and thirdgeneration Asian-Americans when they are confronted with cultural conflicts generated by cultural differences between the East and the West. Yao (1983) examined the ethnic awareness of American-born Chinese teenagers in Houston, Texas and concluded that these Chinese-American children have very close ties within the Chinese ethnic community. Yao further pointed out that the primary factors causing social isolation of Chinese-Americans are language barriers and cultural differences.

Cultural differences and misunderstandings often become evident when people from different cultures try to communicate. Research has shown that the average art teacher in the Untied States, who usually has AngloEuropean origins, has very little knowledge about cultures other than his or her own (Congdon, 1986; Lanier 1980; Madiano, 1982; Saville-Trioke, 1984; Stuhr, 1986). Mason's (1988) research, for example, in British schools with Muslim minority children reported lack of understanding by White art teachers about students from different ethnic backgrounds who are in their art classes. For example, a teacher's request of students to draw pictures of their families

Marilyn Zurmuehlen's Working Papers in Art Education 1993 
was ignored by Muslim students because of their religious restrictions on the painting and drawing of the human figure.

\section{Cultural Conflicts}

From Wurzei's point of view (1988), cultural conflict occurs when interpretations of cultural patterns of information are not shared with others. It is reflected in the internal (personal) and interactional (social) tensions that arise when different systems of knowledge confront one another. Consequently, results of cultural conflict vary in degree of intensity: from miscommunication, reinforcement of false perceptions, and different forms of hostility, to individual and social feelings of depression, marginality, and alienation. Wurzel emphasizes that the most damaging social conflict occurs when one group forces its ways upon another.

\section{Awareness of Role Models in Art}

Bersson (1986) indicated that in a hierarchical capitalist society, with its inevitable class divisions, art educators always find themselves caught in the dialectical middle between the high culture of the art world and the multicultural life-worlds of the populations they serve. Within the hierarchy of the arts in the Western world, folk art and crafts are separate from fine art. Fine art has much higher status than folk art and crafts. Some researchers (Grigsby, 1977; McFee, 1991) pointed out that most art textbooks and art classes include only Western fine art which by its criteria of selection is often interpreted to mean that all other arts are not worthy of inclusion as "real art" (McFee, 1991).

Consequently, in college art departments, many artists, art critics, art historians, and art educators pass on the most cherished values of the Western fine arts traditions to their students. Those art education students, who will be future art teachers, receive part or all of their training in university art departments where traditions, beliefs, and values of the Western art world usually are taught to the exclusion of concerns of other groups (Hobbs, 1981).

Stokrocki, an art educator, conducted a case study of a Puerto-Rican art teacher and her Puerto-Rican students. She found that class and cultural differences are noted also between the Hispanic teacher and her Hispanic students. The differences are found in the students' permissive and laid-back educational backgrounds and the art teacher's American educational training. Stokrocki concluded that "under such restraints and pressures, art may or may not offer beginning Puerto-Rican students a positive means of selfexpression and self-esteem. Unless art appreciation activities are expanded to include art examples from the students' Hispanic-American folk backgrounds and contemporary cultures, few models will be available to which they can relate" (p. 18). 


\section{Ethnicity and Community}

Given art and cultural transmission as major concerns in multicultural education, there are a wide variety of ways that members of a cultural group can transmit their culture to the younger generation. Although some of this transmission takes place in schools, much of it also takes place in homes, churches, and neighborhoods (Sleeter and Grant, 1988). In a survey by Grant (1981), she found that most teachers did not know how and where students were spending their time outside school, nor were they aware of available community resources. Sleeter and Grant (1988) concluded that "issues outside the classroom that are directly related to multicultural education must be addressed" (p. 437). Young (1990) also pointed out the important role that a minority family can play as mediators for their children's art and academic education.

In 1982, the Ethnic Heritage and Language Schools Project undertaken by the American Folklife Center issued a report about thirteen community-based ethnic schools. In this study, each community-based school's perception of itself and its knowledge was discussed. Their curricula show what each community perceives as important components of its ethnic identity with language, religion, and history as the focus of classes. As forums for learning and presenting songs, dances, art, crafts, and other traditions, community-based schools play an important role in formulating and defining what constitutes ethnic cultural expressions for specific groups of students. This investigation recognized the importance of community-based ethnic schools in helping the Untied States retain its multicultural profile and noted that further study is warranted (Bradunas, 1988).

\section{Objectives}

The objectives of my research are the following:

1. To investigate who a particular Chinese community-based school serves and under what philosophy it operates. How do children enter and leave the program? What constitutes their education in the program? What do administrators and teachers perceive the program to be?

2. To investigate sociocultural dynamics of how art is taught and learned in a particular Chinese school. I will investigate what art model is served, how art curriculum is designed, and what are the students' attitudes toward art leaning.

3. To explore how art, taught at the regular public school, compares with art taught at the Chinese community-based school in respect to sociocultural dynamics.

4. Ultimately, I wish to examine whether Chinese-American students' Chinese art learning experiences bring any significant impacts as described in 
Wurzel's multicultural model, in respect to the processes of self-awareness, self-identity, cultural difference, cultural conflict, and the acceptance of other cultures.

\section{Chinese School}

Fishman, a sociologist, conducted research about community-based ethnic heritage and language schools (1966) and categorized communitybased schools into three types: (1) all-day schools, (2) weekday after-hours schools, and (3) weekend schools. According to Fishman (1966), all day schools are generally private schools affiliated with religious institutions. They incorporate ethnic language and cultural instruction into the regular school day. Weekday after-hours schools are in session during one or more weekday afternoons or evenings. The Chinese school where I am conducting my research belongs to the third category of weekend schools. Weekend schools are held on Saturdays or Sundays. The Chinese community-based school I am studying meets on Saturdays. Attendance is in addition to attendance at regular public schools. The reason I chose to conduct my study at a weekend school is because there are no all day schools and after-hours Chinese community-based schools in the Chicago area.

This Chinese community-based school is located in a west suburban area of Chicago. In the initial phase of this study, about thirty ChineseAmerican students in art class, ranging in age from six to fifteen years, were the focus of my study. Chinese calligraphy, Chinese paper cutting, and Chinese painting activities are being observed. In order to get profound information and to have deep communications with these Chinese-American students, parents, and teachers, both Chinese and English languages are being included during the period of data collection.

\section{Methodology}

A qualitative case study methodology is the research design for the present study (Glaser \& Strauss, 1967; Lincoln \& Guba, 1985; Walcott, 1988; Yin, 1984). Multiple sources of data will be utilized in this study:

(1) classroom observations of Chinese-American students attending Chinese language and art classes in the Chinese community-based school, (2) essays written by students, (3) focus group discussions with Chinese-American students, (4) selected individual interviews with Chinese-American students, (5) individual interviews with art teachers both at the Chinese communitybased school and at a selected public school, (7) students' art products,

(8) researcher fieldnotes taken while observing, (9) school records, and (10) interview records (transcripts and tapes). While some data sources (e.g., observations, essays, and interviews) are being identified at the outset, other sources may emerge as the study proceeds.

Taken together, I hope that this case study will provide significant insights for educators and art educators specifically to have a better 
understanding about Chinese-American students' experiences of selfawareness, cultural differences, cultural conflicts, and the acceptance of other cultures through art learning. Results of this study also should inform the theory and practice of multicultural art education for Chinese-American students in regular public schools.

\section{References}

Banks, J. A. (1981). Multiethnic education: Theory and practice. Boston, MA: Allyn and Bacon.

Bennett, C. (1986). Comprehensive multicultural education. Boston, MA: Allyn \& Bacon.

Bersson, R. (1986). Why art education lacks social relevance: A contextual analysis. Art Education, 38 (1), 41-45.

Bradunas, E (Ed.) (1988). Ethnic heritage and language schools in America. Washington, DC: American Folklife Center.

Congdon, K. (1986). Meaning and use of folk speech. Studies in Art Education, 27 (3), 140-148.

Eisner, E. (1991). The enlightened eye. New York: Macmillan.

Fishman, J. (1966). Language loyalty in the United States. Netherlands: Mouton \& Co.

Glaser, B. G., \& Strauss, A. L. (1967). The discovery of grounded theory. Chicago, IL: Aldine.

Goodenough, W. (1971). Culture, language and society. Reading, MA: Addison-Wesley.

Grant, C. A. (1981). The community and multiethnic education. In J. A. Banks (Ed.), Education in the 80's: Multiethnic education (pp. 128139). Washington, DC: National Education Association.

Grigsby, J. E, Jr. (1977). Art \& ethnics: Background for teaching youth in a pluralistic society. Dubuque, IA: Wm. C. Brown.

Hernandez, H. (1989). Multicultural education. Columbus, $\mathrm{OH}$ : Merrill.

Hill, E. P. (1990). Shattered fantasy: Minority access to careers in art education. In B. Young (Ed.), Art, culture, and ethnicity (pp. 219-230). Reston, VA: National Art Education Association. 
Hobbs, J. A. (1981). Established ways of thinking. Bulletin of the Way Caucus on Social Theory and Art Education, 1, 3-11.

Lanier, V. (1980). Art and the disadvantaged. In G. Battcock (Ed.), New ideas in art education (pp. 181-202). New York: E. P. Dutton.

Lincoln, Y. \& Guba, G. (1985). Naturalist inquiry. Newsbury, CA: Sage.

Madiano, N. (1982). Accurate perception of colored illustration, rates of comprehension in Mexican American children. The Journal of Cross-Cultural Psychology, 13 (4), 490-495.

Mason, R. (1988). Art education and multiculturalism. London: Croom Helm.

McFee, J. K. (1991). Art education progress: A field of dichotomies or a network of mutual support. Studies in Art Education, 32 (2), 70-82.

Newman, W. N. (1973). A study of minority groups and social theory. New York: Harper \& Row.

Saville-Troike, M. (1984). Navaho art and education. Journal of Aesthetic Education, 18 (2), 40-50.

Sleeter, C., \& Grant, C. (1987). An analysis of multicultural education in the United States. Harvard Education Review, 57 (4), 421-439.

Sleeter, C., \& Grant, C. (1988). Making choices for multicultural education. Columbus, $\mathrm{OH}$ : Merill.

Stokrocki, M. (1991). Teaching art to Hispanic children from a Hispanic perspective: A prevalence of patterning and pressure. (ERIC Document Reproduction Service No. ED 341616).

Stuhr, P. L. (1986). A field research study which analyses ethnic values and aesthetic/art education: As observed in Wisconsin Indian community schools. (ERIC Document Reproduction Service No. ED 276540).

Wolcott, H. (1988). Ethnographic research in education. In R. Jaeger (Ed.), Complementary methods: For research in education (pp. 188-202). Washington, DC: American Educational Research Association.

Wurzel, J. (1988). Toward multiculturalism. Yarmouth, ME: Intercultural Press.

Yao, E. (1983). Ethnic awareness of Chinese-American teenagers. Urban Education, 18 (1), 71-78. 
Yin, R. (1984) Case study research: Design and methods. Newsbury Park, CA: Sage.

Young, B. (1990). The minority family as a mediator for their children's art and academic education. In B. Young (Ed.), Art, culture, and ethnicity (pp. 33-52). Reston, VA: National Art Education Association.

Zimmerman, E. (1991). Teaching art from a global perspective. (ERIC Document Reproduction Service No. ED 329490) 